Article

\title{
Promoting Cooperation of Monitoring, Control, and Surveillance of IUU Fishing in the Asia-Pacific
}

\author{
Iwao Fujii ${ }^{1,2, *}$, Yumi Okochi ${ }^{3}$ and Hajime Kawamura ${ }^{3}$ \\ 1 Ocean Policy Research Institute, Sasakawa Peace Foundation, Tokyo 105-8524, Japan \\ 2 Graduate School of Agricultural and Life Sciences, University of Tokyo, Tokyo 113-8657, Japan \\ 3 Japan NUS Co., Ltd., Tokyo 160-0023, Japan; okochi-y@janus.co.jp (Y.O.); kawamura-hjm@janus.co.jp (H.K.) \\ * Correspondence: i-fujii@spf.or.jp; Tel.: +81-351-575-248
}

check for

updates

Citation: Fujii, I.; Okochi, Y.;

Kawamura, H. Promoting

Cooperation of Monitoring, Control,

and Surveillance of IUU Fishing in

the Asia-Pacific. Sustainability 2021,

13, 10231. https://doi.org/

$10.3390 /$ su131810231

Academic Editors: Do-Hoon Kim,

Mitsutaku Makino and

Chung-Ling Chen

Received: 29 July 2021

Accepted: 7 September 2021

Published: 13 September 2021

Publisher's Note: MDPI stays neutral with regard to jurisdictional claims in published maps and institutional affiliations.

Copyright: (C) 2021 by the authors. Licensee MDPI, Basel, Switzerland. This article is an open access article distributed under the terms and conditions of the Creative Commons Attribution (CC BY) license (https:// creativecommons.org/licenses/by/ $4.0 /)$.

\begin{abstract}
Illegal, unreported, and unregulated (IUU) fishing is becoming a growing threat to sustainable fisheries and the economy worldwide. To solve this issue, various efforts on monitoring, control, and surveillance (MCS) have been made at the national, regional, and international levels. However, there is still the lack of measures against IUU fishing vessels at the multilateral level. Here, we assessed the situations of fisheries, and the current systems and challenges of MCS in eight Asia-Pacific countries with a focus on MCS of IUU fishing vessels at sea. Through a literature review and interviews, we confirmed that IUU fishing was linked with the status of fisheries in each country, and that each country implements various MCS measures with different emphases. However, there was a trend of enhancing or newly establishing four areas of MCS: vessel tracking, patrol, onboard observers, and port State measures, with amended or newly adopted laws. We also identified challenges of MCS such as insufficient MCS in coastal areas and fragmented cooperation among the countries. Based on our findings, we advance several recommendations including the enhancement of cooperation among stakeholders, especially fishers, for co-monitoring in coastal areas and the establishment of a communication platform for Asia-Pacific countries.
\end{abstract}

Keywords: IUU fishing; MCS; vessel tracking; patrol; inter-regional cooperation

\section{Introduction}

Illegal, unreported, and unregulated (IUU) fishing threatens sustainable fisheries, and the economy dependent upon them. One estimate shows that the global catch derived from illegal and unregulated fishing can range from 11,000,000 to 26,000,000 t annually [1]. As the current annual catch of marine capture fisheries is 96,400,000 $t$ (as of 2018) [2], the amount of catch from illegal sources can be significant. However, illegal catch is not usually reflected in official fishery data, and thus can undermine the robustness of fisheries management [3]. Furthermore, IUU fishing is reported to have caused an annual economic loss of USD 5 billion in the Asia-Pacific alone [4], whereas the worldwide economic loss of illegal and unregulated catch is estimated to be USD 10 to 23.5 billion [1]. Due to its clandestine nature, visualizing the impacts of IUU fishing remains challenging [5].

There are various forms of IUU fishing. The Food and Agricultural Organization (FAO) defines IUU fishing as broad activities including: (1) fisheries conducted without permission or in contravention of national laws, and conservation and management measures (CMMs) of the Regional Fisheries Management Organizations (RFMOs), or international obligations (illegal fishing); (2) fisheries unreported or misreported in contravention of national laws or regulations, or reporting procedures of the RFMOs (unreported fishing); and (3) fisheries in an RFMO area conducted by vessels without nationality or flying the flag of a non-State party to that organization in contravention of CMMs, or fisheries in an area without CMMs conducted in a manner inconsistent with State responsibilities under international law (unregulated fishing) [6]. IUU fishing involves various activities and 
actors, and thus requires comprehensive, interdisciplinary approaches to its solution [7]. Collaborative efforts are also vital to stakeholders and countries [8].

To tackle IUU fishing, various monitoring, control, and surveillance (MCS) efforts have been made. The International Plan of Action to Prevent, Deter, and Eliminate IUU Fishing (IPOA-IUU) is the first (voluntary) international instrument, adopted in 2001. It encourages all States to use available measures (including coastal and port States, and market-related measures) in an integrated manner, stressing the primary responsibility of the flag States [9]. The Agreement on Port State Measures (PSMA) is another (but legally binding) international instrument, adopted in 2009. Its objective is to prevent, deter, and eliminate IUU fishing by preventing vessels engaged in IUU fishing from using ports and landing their catches [10]. Furthermore, Target 14.4 of the 14th Sustainable Development Goal (SDG14: Life below water) has set a goal to end IUU fishing by 2020 [11], although it has not yet been achieved.

Under the IPOA-IUU, several regions have developed a Regional Plan of Action (e.g., RPOA-IUU of Southeast Asia) [12]. Other important frameworks at the regional level are the RFMOs in which various CMMs are implemented to prevent IUU fishing (e.g., vessel monitoring system (VMS), onboard observers) [13]. The EU's IUU Regulation is another regional effort under which countries are banned from exporting their fishery products to the EU if they are considered non-cooperative in IUU fishing prevention [14]. The Southeast Asian Fisheries Development Center (SEAFDEC) and the Forum Fisheries Agency (FFA) also take various cooperative measures against IUU fishing (e.g., capacity building of the port State measures (PSM) and joint surveillance, respectively) $[15,16]$.

At the national level, many countries have established a National Plan of Action (NPOA-IUU) under the IPOA-IUU, and many more employ a range of MCS measures [17]. National MCS efforts include vessel registration (flag State responsibility), vessel monitoring (flag and coastal State responsibility), port inspection (port State responsibility), and catch documentation (market State responsibility). The focus of MCS may vary depending on the situation of fisheries and IUU fishing in each region and country [9].

Despite various existing efforts on MCS, IUU fishing continues to threaten sustainable fisheries and the economy [1]. One reason is the limited capacity of MCS in the flag and coastal States. Another possible reason is insufficient multilateral cooperation in MCS targeting IUU fishing vessels at sea, while there is a growing amount of effort on port and market State measures (but see [16,18]). However, there has been little investment in the study of MCS, except by countries such as China and Korea, e.g., $[19,20]$. Specifically, China has drawn attention from many researchers due to frequent cases of its vessels being reported to have committed illegal fishing activities worldwide [19,21]. In response to increasing criticism against illegal Chinese distant water fishing vessels in international fora, China revised its Distant Water Fishing Management Regulations in 2020 [22]. China also put its coast guard under the command of the People's Armed Police Force in 2018 [23]. One reason behind this move may be to strengthen surveillance of foreign fishing vessels within the EEZ of China, especially the South and East China Sea, where territorial disputes with neighboring countries exist [21,23]. Similar movements have occurred in other countries, yet they have received relatively little attention.

To fill the information gap of MCS, we address the following questions for multiple countries in the Asia-Pacific: (1) Why does IUU fishing still occur? (2) What do we need to further strengthen MCS? We selected this region because it is the largest producer of fish and the hot spot of IUU fishing [4,24]. To address the questions, we aimed to reveal: (1) the current status of IUU fishing; (2) the current system of MCS; and (3) the effectiveness and challenges of MCS in eight countries (Figure 1). They were selected based on: (1) contribution to the world's fishery production (Table 1), or the significance of the fisheries sector to the domestic economy; and (2) availability of information (which probably indicates remarkable MCS) while considering geographical balance. The scope of this study is the role of flag States in MCS of domestic vessels operating inside and outside their jurisdiction and that of coastal States in MCS of domestic and foreign vessels 
operating within their jurisdiction. Additionally, since PSM have become a mainstream part of MCS, we studied the implementation status of these measures.

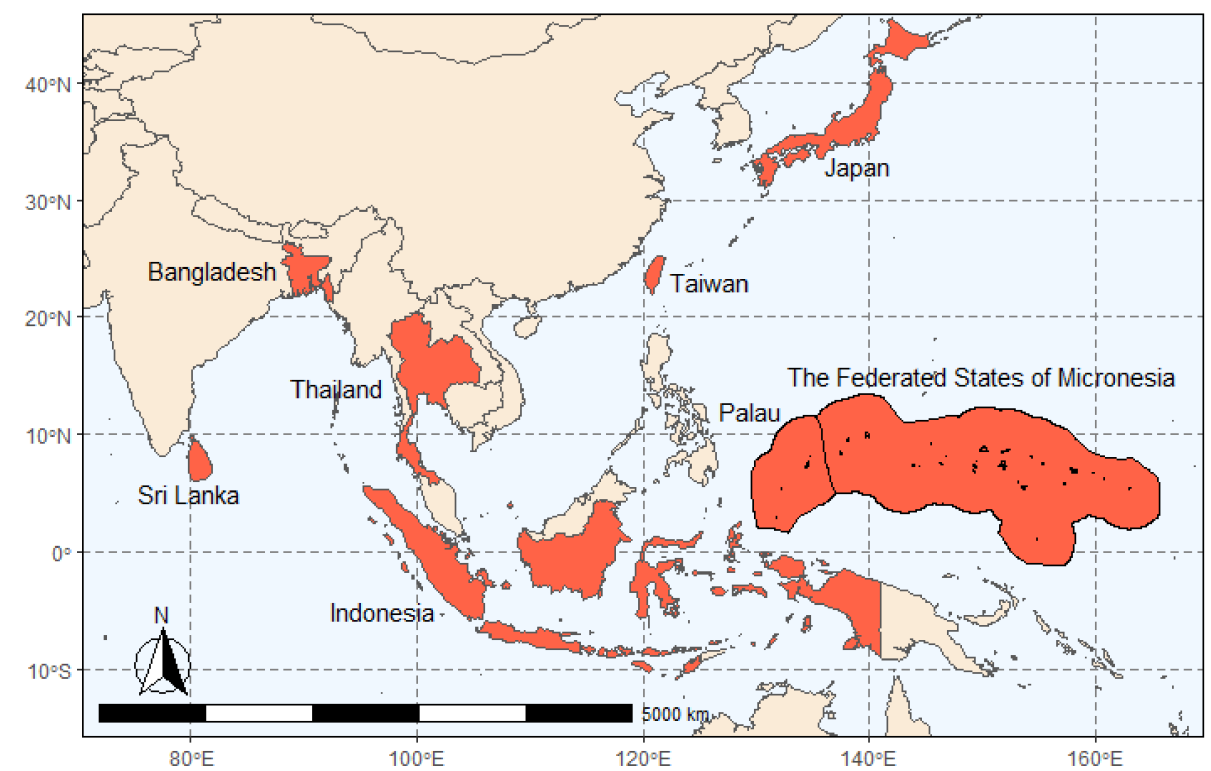

Figure 1. Locations of the eight Asia-Pacific countries studied in this research.

Table 1. Total annual catch and ranking in marine capture fisheries in the eight Asia-Pacific countries.

\begin{tabular}{|c|c|}
\hline Country & $\begin{array}{c}\text { Domestic Production } \\
\text { (Million Tons, Live Weight) }\end{array}$ \\
\hline Japan & 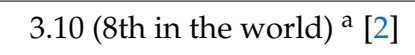 \\
\hline Taiwan & 0.81 (22nd in the world) $^{a}$ [2] \\
\hline Indonesia & 6.71 (3rd in the world) ${ }^{\text {a }}[2]$ \\
\hline Thailand & 1.51 (12th in the world $)^{a}$ [2] \\
\hline Bangladesh & $0.65^{\mathrm{b}}[25]$ \\
\hline Sri Lanka & $0.41^{\mathrm{c}}[26]$ \\
\hline Palau & $0.01^{\mathrm{d}}[27]$ \\
\hline Federated States of Micronesia & $0.17^{\mathrm{e}}[28]$ \\
\hline
\end{tabular}

Note: a Annual catch in 2018. ${ }^{\mathrm{b}}$ Annual catch between 2017 and 2018. ${ }^{\mathrm{c}}$ Annual catch in 2019. ${ }^{\mathrm{d}}$ Total annual catch calculated based on data from different years with nearshore catch in 2000 and offshore catch in 2014. ${ }^{\text {e }}$ Total annual catch of offshore and distant water fisheries in 2019 (no data of nearshore catch found).

\section{Materials and Methods}

As was done by Mackay et al. [29], we conducted a literature and media review. First, we extracted information from documents issued by the national governments, regional intergovernmental organizations, and United Nations organizations. We then reviewed peer-reviewed journals about MCS of the eight countries to collect relevant information. When more information was deemed necessary, we referred to research reports by various organizations (e.g., NGOs or private firms) and then online news articles to supplement the collected information. Second, we conducted interviews with MCS officials in each country using a semi-structured method (Appendices A and B) [30]. Through the interviews, we clarified the accuracy of the collected information and asked whether there was any update that could not be covered in our literature and media review. 


\section{Results}

\subsection{Overview of Fishery Status and IUU Fishing}

There were three types of conditions where either: (1) domestic vessels or (2) foreign vessels are a major cause of IUU fishing; or (3) both foreign and domestic IUU fishing vessels are significant issues. Taiwan falls under the first condition, whereas the two Pacific countries (Palau and the Federated States of Micronesia) are categorized under the second condition. Other Asian countries (i.e., Japan, Indonesia, Thailand, Bangladesh, and Sri Lanka) face issues related to the third condition. Recreational fishing can be another source of IUU fishing [31]. Although there were few reported cases of law violation by recreational fishers in the eight countries (but see [32]), their catch is considered underreported [33]. Therefore, further investigation would be needed for the Asia-Pacific. Note that the information we report in this study indicates the emphasis of IUU fishing or MCS by each country rather than exhaustively covering all relevant information.

Japan is the 8th largest producer of marine capture fisheries [2]. It was estimated to operate the third-largest DWF fleet globally based on automatic identification system (AIS) data (2016-2017) [34]. However, more than $85 \%$ of fishery management entities are engaged in small-scale coastal fisheries using boats of less than $20 \mathrm{~m}$ [35]. Japan also allows vessels from neighboring countries, namely China, Korea, Russia, and Taiwan, to operate within its exclusive economic zone (EEZ) under bilateral agreements. However, Chinese and Korean fishing vessels are not currently allowed in the EEZ of Japan due to the rupture of bilateral negotiations [36]. The distinctive characteristic of IUU fishing in Japan is the increasing number of cases of coastal poaching by entities with no fishing rights [37]. Moreover, illegal fishing (e.g., unlawful shark finning and trafficking) by Japanese-flagged vessels has been reported overseas [38]. With regard to IUU fishing by foreign fishing vessels, unpermitted vessels from neighboring countries are often found entering the EEZ of Japan. These vessels conduct activities such as unauthorized deployment of fishing gear [39]. There are also cases where legitimate foreign vessels infringe on the conditions set under the bilateral agreements on fisheries.

Taiwanese DWF vessels (vessels in high seas or overseas waters [40]) operate worldwide [41]. An estimate based on AIS data (2016-2017) shows that Taiwanese vessels are the second most prolific DWF vessels after those of China [34]. Taiwan has long been criticized for illegal fishing by vessels and unregulated fishing by the flag of convenience (FOC) vessels operated by Taiwanese owners. In 2005, Taiwan was condemned for FOC vessels fishing in excess of the designated catch limit deemed by the International Commission for the Conservation of Atlantic Tunas (ICCAT) [42]. This led to a sanction on Taiwan, reducing about $75 \%$ of Taiwan's catch quota for the following year. In addition, fish laundering by Taiwanese vessels has been reported in the ICCAT [42,43]. In 2015, a Taiwanese-flagged vessel was accused of illegal fishing by an international NGO [44]. Taiwan's non-compliance with international obligations of combating IUU fishing resulted in the issuance of a yellow card warning by the EU to Taiwan in 2015 under the EU's IUU Regulation (lifted in 2019) [45]. Recent data show that fines imposed on FOC vessels have decreased [41], but Taiwanese vessels are still reported to be detained for illegal activities [46].

Indonesia is the third-largest producer of marine capture fisheries after China and Peru [2]. Thailand, on the other hand, is the 12th largest producer, but the fourth-largest exporter of fishery products, including re-exporting products [2]. A characteristic of fisheries in the two countries is the remarkably higher number of small vessels in coastal fisheries compared to that of large vessels in offshore and high seas fisheries [47,48]. In Indonesia and Thailand, both domestic and foreign IUU fishing vessels are considered significant issues. In Thailand, various types of illegal fishing are reported in domestic fisheries, including fishing in prohibited areas or seasons, use of illegal fishing gear, and catching of prohibited species (interview). Vessels fishing without authorization or in breach of license conditions and illegal trawl fishing have also been reported in Indonesia [49,50]. Issues that both countries have in common are forced labor and human trafficking, which are 
often interlinked with domestic IUU fishing (Insufficient measures of MCS led Thailand to receive a yellow card warning from the EU in 2015, which was lifted in 2019) [51,52]. Unpermitted fishing by foreign vessels has also been reported. Indonesia especially considers this issue as a serious encroachment by foreign vessels. Fishing vessels from China are involved in a territorial dispute between the two countries, as they are often found within the EEZ of Indonesia, part of which overlaps with the area within the nine-dash line claimed by China [53].

Bangladesh and Sri Lanka have relatively smaller marine capture fisheries compared to other Asian countries [25,26]. However, the growth rates of the two countries in this sector have been increasing rapidly over the past three decades. Both countries are similar to the two Southeast Asian countries in that they have a higher number of small vessels compared to large vessels $[25,26]$. Both domestic and foreign IUU fishing vessels are mentioned as issues to tackle in the two countries as well. In Bangladesh, illegal activities by domestic fishers include the use of illegal fishing gear [54], and fishing in prohibited areas (e.g., trawlers entering areas with a depth of less than $40 \mathrm{~m} \mathrm{[55])} \mathrm{and} \mathrm{seasons} \mathrm{(e.g.,}$ fishing during a ban in Hilsa fisheries [54]). Sri Lanka faces a similar issue in regard to IUU fishing in domestic fisheries [56]. In addition, some Sri Lankan vessels were also found fishing illegally in foreign waters (Sri Lanka received a yellow card warning from the EU in 2012 and then a red card (export ban) in 2014 (lifted in 2016).) [57]. Fishing by unpermitted vessels from neighboring countries is a common issue in Bangladesh and Sri Lanka [58,59]. Sri Lanka faces high-profile capture of vessels from Tamil Nadu State, India [59].

Under the framework of the Vessel Day Scheme (VDS) of the Nauru Agreement, Palau and the Federated States of Micronesia allow foreign fishing vessels to operate within their EEZ [60]. Foreign vessels authorized to operate there are mostly tuna longline or purse sein vessels from Japan, Taiwan, Korea, China, and the United States [61,62]. The Federated States of Micronesia also have several vessels operating in foreign waters [28]. Illegal activities by foreign fishing vessels often occur in these two countries. One such activity reported is the poaching of coastal resources by unlicensed small wooden boats (so-called blue boats) from Southeast Asia [63,64]. Illegal activities by large vessels reported in Palau include fishing tuna using unauthorized fish aggregating devices offshore and unauthorized transshipment of catch in high seas adjacent to the Palauan EEZ [63]. The Federated States of Micronesia also reported unpermitted operations within its EEZ and legitimate vessels that did not adequately report catch [65]. The FFA estimated that the amount of fish either harvested or transshipped illegally in the Pacific region is worth USD 600 million, with an annual economic loss of USD 150 million [66].

\subsection{MCS Measures}

There has been a growing effort in MCS in the eight countries, especially in the past decade. Various types of MCS measures have been enhanced or newly established, depending on the conditions of IUU fishing in each country (Tables 2 and 3). Major MCS measures included vessel tracking (mainly for domestic fishing vessels), visual surveillance (especially patrol at sea for both domestic and foreign vessels), onboard observers (for domestic vessels), and PSM (for foreign vessels). For improvement of MCS, there is a trend toward amending or establishing laws and regulations with an emphasis on regulating domestic offshore and high seas fishing vessels in the studied countries. 
Table 2. Vessel tracking policies using the vessel monitoring system (VMS) and the automatic identification system (AIS) in the eight Asia-Pacific countries.

\begin{tabular}{|c|c|}
\hline Country & Vessel Tracking Requirement \\
\hline Japan & $\begin{array}{l}\text { - VMS required for domestic offshore and distant water } \\
\text { fishing vessels permitted by the Minister of Agriculture, } \\
\text { Forestry and Fisheries }\end{array}$ \\
\hline Taiwan & - $\quad$ VMS required for domestic distant water fishing vessels \\
\hline Indonesia & - VMS required for domestic vessels of 30 gross tons or over \\
\hline Thailand & $\begin{array}{l}\text { - } \quad \text { VMS required for domestic vessels of } 30 \text { gross tons or over } \\
\text { - } \quad \text { AIS required for foreign vessels landing catch in Thai ports }\end{array}$ \\
\hline Bangladesh & $\begin{array}{l}\text { VMS and AIS required for domestic commercial vessels } \\
\text { (all trawlers) } \\
\text { - } \quad \text { AIS required for boats and vessels in other fisheries }\end{array}$ \\
\hline Sri Lanka & $\begin{array}{l}\text { - VMS required for domestic high seas multi-day vessels of } \\
10.3 \mathrm{~m} \text { or over }\end{array}$ \\
\hline Palau & $\begin{array}{l}\text { - VMS and AIS required for all vessels operating within the } \\
\text { Domestic Fishing Zone (designated area open to fishing in } \\
\text { the EEZ of Palau) }\end{array}$ \\
\hline Federated States of Micronesia & $\begin{array}{l}\text { - VMS required for all vessels operating inside EEZ of the } \\
\text { Federated States of Micronesia and domestic vessels } \\
\text { operating outside its EEZ }\end{array}$ \\
\hline
\end{tabular}

Table 3. Monitoring, control, and surveillance (MCS) measures implemented in the eight Asia-Pacific countries. All of the countries implement each of four MCS measures (i.e., vessel tracking, patrol, onboard observers, and port State measures (PSM) ) unless otherwise noted in gray and subsequent notes. Years in which MCS measures were enhanced or newly established are indicated in yellow and blue, respectively. Asterisks $\left(^{*}\right)$ indicate the countries that became parties to the Agreement on Port State Measures (PSMA), but the other countries also implement PSM.

\begin{tabular}{|c|c|c|c|c|c|}
\hline \multirow[b]{2}{*}{ Country } & \multicolumn{5}{|c|}{ MCS Measures Being Implemented } \\
\hline & Vessel Tracking & Patrol & $\begin{array}{l}\text { Onboard } \\
\text { Observer }\end{array}$ & PSM & $\begin{array}{c}\text { Other Measures or } \\
\text { Relevant Information }\end{array}$ \\
\hline Japan & 2018 & 2018 & 2012 & $2017 *$ & $\begin{array}{l}\text { - } \quad \begin{array}{l}\text { New fisheries act } \\
(2018)\end{array} \\
\text { New surveillance } \\
\text { headquarters } \\
(2018)\end{array}$ \\
\hline Taiwan & 2016 & & 2016 & 2016 & $\begin{array}{l}\text { - New distant water } \\
\text { fisheries act (2016) }\end{array}$ \\
\hline Indonesia & & 2014 & & $2014 *$ & $\begin{array}{ll}\text { - } & \text { Satellite images for } \\
\text { - } & \text { vessel tracking } \\
\text { New surveillance } \\
\text { agency (2014) } \\
\text { - Interagency } \\
\text { cooperation (2020) }\end{array}$ \\
\hline
\end{tabular}


Table 3. Cont.

\begin{tabular}{|c|c|c|c|c|c|}
\hline \multirow[b]{2}{*}{ Country } & \multicolumn{5}{|c|}{ MCS Measures Being Implemented } \\
\hline & Vessel Tracking & Patrol & $\begin{array}{l}\text { Onboard } \\
\text { Observer }\end{array}$ & PSM & $\begin{array}{c}\text { Other Measures or } \\
\text { Relevant Information }\end{array}$ \\
\hline Thailand & 2015 & & 2015 & $2016 *$ & $\begin{array}{ll}- & \text { New fisheries } \\
\text { ordinance (2015) } \\
\text { - } \quad \text { Interagency } \\
\text { cooperation (2015) } \\
\text { - } \quad \text { Port control for } \\
\text { domestic vessels } \\
(2015)\end{array}$ \\
\hline Bangladesh & 2020 & & a & $2019 *$ & $\begin{array}{l}\text { - } \quad \text { New fisheries act } \\
\text { (2020) } \\
\text { MCS measures } \\
\text { being introduced } \\
\text { with the World } \\
\text { Bank (2019-2023) }\end{array}$ \\
\hline Sri Lanka & 2015 & & 2014 & $2011 *$ & $\begin{array}{l}\text { - New high seas } \\
\text { fisheries } \\
\text { regulations } \\
(2014-2015)\end{array}$ \\
\hline Palau & & 2012 & $\mathrm{~b}$ & 2015 * & $\begin{array}{l}\text { - Joint surveillance } \\
\text { with FFA member } \\
\text { States under the } \\
\text { Niue Treaty } \\
\text { Subsidiary } \\
\text { Agreement (2012) }\end{array}$ \\
\hline $\begin{array}{c}\text { Federated States of } \\
\text { Micronesia }\end{array}$ & & 2012 & & & $\begin{array}{l}\text { - } \quad \text { Shiprider with the } \\
\text { US Coast Guard }\end{array}$ \\
\hline
\end{tabular}

Note: a Bangladesh is currently planning to introduce the observer program. b Palau currently has no active high seas vessels and thus, has no observer program.

\subsubsection{Vessel Tracking Using VMS and AIS}

The VMS is a common measure employed in the eight countries to monitor fishing vessels. Some countries also require the AIS with the primary purpose of ensuring the safety of vessels. Vessel-tracking policies vary across the eight countries. They are set based on either: (1) type of fishery/location where vessels operate; or (2) size (weight or length) of vessels (Table 2). Asian countries aim to monitor domestic vessels in vessel monitoring, whereas the Pacific countries mainly target vessels operating in their EEZs.

Japan and Taiwan require offshore and/or DWF vessels to carry the VMS. Under the Fisheries Act of Japan, the VMS is mandatory for vessels designated as "fisheries permitted by the Minister of Agriculture, Forestry and Fisheries" (vessels in offshore areas, high seas, and foreign waters) (Appendix C) [67]. The Act stipulates that the vessels must report their positions when sailing and fishing using a satellite ship positioning transmitter or other electronic equipment specified by the government. The Ministerial Ordinance on the Permission, Regulation, etc., of Designated Fisheries further stipulates details including the prevention of falsified transmission of VMS data [68]. Similarly, Taiwan requires DWF vessels to carry the VMS under the Act for Distant Water Fisheries [40]. The Regulations on the Management and Guidance of the Equipment for Vessel Position Reporting, Catch Reporting, Navigational Chart, and Monitoring Center prescribe details of how the VMS should work, such as the frequency of reporting positions of vessels [69].

Indonesia and Thailand specify fishing vessels that need the VMS by tonnage. Indonesia requires vessels of 30 gross tons or more to carry an active VMS under the Regulation of the Minister of Marine and Fisheries of the R.I. No. 42/Permen-Kp/2015 about Fishing 
VMS [70,71]. In Thailand, the Royal Ordinance on Fisheries B.E. 2558 (2015) stipulates the VMS requirement [72]. The NPOA-IUU of Thailand explains that vessels of 30 gross tons or more must transmit signals every hour [73]. In addition, foreign fishing vessels need to be monitored through the AIS as a prerequisite for entering ports in Thailand [74].

As for Bangladesh and Sri Lanka, Bangladesh is currently introducing the VMS and AIS. Under the Marine Fisheries Act passed in 2020, and the subsequent Marine Fisheries Rules currently being drafted, industrial vessels (all trawlers) need to install both the VMS and AIS as prerequisites for obtaining a fishing license (interview). In addition, artisanal boats and mechanized vessels in other fisheries need the AIS (interview). In contrast, Sri Lanka requires multi-day fishing vessels operating in high seas to install the VMS under the Fisheries and Aquatic Resources Act No. 2 of 1996 [75]. The Implementation of Satellite-based VMS for Fishing Boats Operating in High Seas Regulations further stipulate that high sea vessels of $10.3 \mathrm{~m}$ or more must provide the required information through the VMS every four hours [76].

Vessel tracking of the two Pacific Island countries (Palau and the Federated States of Micronesia) is unique in that they mainly target fishing vessels operating in their EEZ (both domestic and foreign). Palau closes fisheries in $80 \%$ of its EEZ, designated as the Palau National Marine Sanctuary, and allows fishing vessels to operate in the remaining $20 \%$ open as the domestic fishing zone (DFZ). All vessels must install both the VMS and AIS while fishing within the DFZ under the Palau National Marine Sanctuary Act [77]. The Federated States of Micronesia requires all vessels to install the VMS when they operate in its EEZ under the Marine Resources Act of 2002 [78]. Its NPOA-IUU further explains that the VMS is required for all vessels licensed by the Federated States of Micronesia, including domestic vessels operating outside its EEZ [28,79].

\subsubsection{Other Relevant Efforts on MCS}

Other major MCS measures implemented by the eight countries include patrols, onboard observers, and PSM (Table 3). Execution of measures (including vessel tracking) is supported by amended or newly established acts and regulations in these countries.

To strengthen fisheries law enforcement, Japan amended its Fisheries Act in 2018, under which penalties for poaching in coastal areas largely increased (i.e., a three year imprisonment or JPY 30 million penalty at maximum) [37]. The amended Act also designated vessels operating in offshore areas, high seas, and foreign waters as "fisheries permitted by the Minister of Agriculture, Forestry and Fisheries" and required them to install the VMS (previously, no offshore vessels had to carry the VMS) [67]. Japan also established the Fisheries Surveillance Headquarters in 2018 to coordinate all sections and departments relevant to vessel surveillance within the Fisheries Agency through a unified command chain of its Director-General [80]. Regarding onboard observers, the Japan Observer Program was authorized as the Western and Central Pacific Fisheries Commission (WCPFC) Regional Observer Program in 2012 [81]. Furthermore, Japan ratified the PSMA in 2017. Under this agreement, foreign vessels entering ports in Japan are subject to inspection that includes verification of relevant documents and confirmation of catch and fishing gear [82]. Figure 2 shows a change in the amount of budget of the Fisheries Agency of Japan on MCS (2014-2020). Interestingly, a recent trend of the budget exceeding JPY 20 billion coincides with increased Japanese efforts on MCS.

In response to the yellow card warning by the EU, Taiwan enhanced its MCS by adopting the new Act for Distant Water Fisheries in 2016 for domestic fishing vessels, in which the installation of the VMS and electronic logbook system were stipulated [40]. The new Act particularly emphasizes law enforcement through an increase in fines for violations [83]. The Fisheries Act and the Act to Govern Investment in the Operation of Foreign Flag Fishing Vessels were amended in accordance with the new Act. The latter was amended to strengthen regulations of FOC vessels by incorporating the definition of serious violations for the first time [84]. Taiwan is participating in the regional observer programs (ROPs) and high seas boarding and inspection schemes by the RFMOs [83]. 
Under the ROPs, it has increased the number of onboard observers to monitor its DWF vessels. Lastly, although Taiwan is not a party to the PSMA, it implements PSM on foreign vessels and FOC vessels under its own scheme [85]. Despite a series of efforts made on MCS, Taiwan was listed by the United States as the IUU fishing nation in 2021 [86].

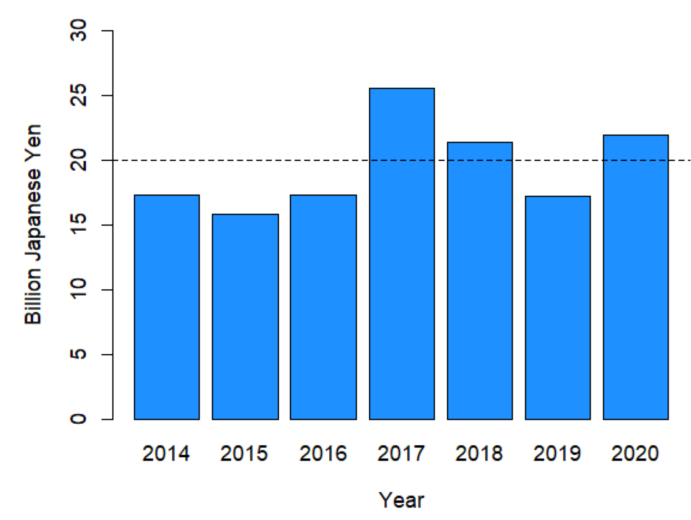

Figure 2. The budget of the Fisheries Agency of Japan on monitoring, control, and surveillance (2014-2020) [87].

Indonesia has long been implementing intensive MCS measures. Currently, at the Bali Radar Ground Receiving Station (BARATA), two satellite missions (Radarsat-2 and Cosmo-Skymed) are mobilized to capture real-time images of fishing vessels at sea. Images are then overlaid with VMS and AIS data to identify suspicious vessels. To improve the operation and cost efficiency of BARATA, a system upgrade has been initiated recently with technical support from Japan under the framework of official development assistance. Other MCS enhancement measures include the establishment of the Indonesian Maritime Security Agency in 2014 [88], and the Indonesian Maritime Information Center (IMIC) in 2020 [89]. The IMIC was launched to enhance coordination among MCS-relevant agencies through information gathering and sharing. What is remarkable about Indonesia's IUU fishing policy is the implementation of special actions including seizing and blowing up illegal fishing vessels, banning fish transfers at sea, and imposing a moratorium on permits for foreign boats in 2014 [90,91]. This hardline policy started under the leadership of the former Minister of Maritime Affairs and Fisheries, Susi Pudjiastuti (2014-2019); however, no case of burning vessels has been reported since late 2019. Indonesia became a party to the PSMA in 2016. As a member of the SEAFDEC, Indonesia has joined regional cooperation to implement PSM [15]. In this cooperation, a series of capacity building programs were conducted by the SEAFDEC [92].

Soon after receiving a yellow card warning by the EU in 2015, Thailand promulgated the Royal Ordinance on Fisheries to ensure compliance with international obligations related to fishery management and MCS, under which vessel monitoring using the VMS and the fishing logbook are stipulated [72]. The new ordinance also requires all vessels to have onboard observers when they fish outside Thai waters [72], especially in areas managed under the Southern Indian Ocean Fisheries Agreement. In the same year, Thailand launched the Command Center Combating Illegal Fishing (CCCIF), a special ad hoc agency to report directly to the prime minister. The CCCIF had a commanding chief of the navy as its commander, and coordinated relevant agencies, including the Department of Fisheries and Ministry of Labor, to strengthen MCS and tackle the forced labor issue [93]. The CCCIF was resolved in 2019 (when the EU's yellow card was lifted) and the Thai Maritime Enforcement Command Center (THAI-MECC) took over the role of the CCCIF. It is composed of the Royal Thai Navy, the Department of Fisheries, and other relevant agencies. Thailand also established the Port In-Port Out Control Centers (PIPO) at 30 locations across the country in 2015. PIPO controls domestic fishing vessels entering and exiting fishing ports by issuing a permit for the fishing trip and validating the accuracy of fishing logbooks through port inspection and the VMS [94]. In addition, Thailand acceded 
to the PSMA in 2016. As part of the SEAFDEC, it has also joined regional cooperation for the implementation of PSM [15]. Furthermore, the Thai Department of Fisheries received technical assistance from OceanMind in implementing its PSM program [95].

To establish a comprehensive MCS system, Bangladesh adopted the new Marine Fisheries Act in 2020, and is currently drafting the Marine Fisheries Rules to enforce the new Act (interview). Along with the VMS and AIS, Bangladesh is planning to introduce onboard observers to industrial fishing vessels, establishing joint MCS centers that will be managed by the Department of Fisheries and connecting other relevant marine and coastal authorities, and expanding its fisher ID card system (for small-scale fishers), which will be linked to GIS data. Implementation of these new systems is conducted as part of the Bangladesh Sustainable Coastal and Marine Fisheries project by the World Bank (2019-2023) [96]. Other MCS measures by Bangladesh include patrols by the coast guard "Operation Jatka (juvenile Hilsa (Tenualosa ilisha))" and the fishery protection campaigns by the navy for this species (Hilsa is considered one of the most important commercial species in Bangadesh) [97]. Lastly, Bangladesh ratified the PSMA in 2019.

Sri Lanka is currently focusing on high seas fisheries in the enhancement of MCS. It adopted a series of MCS regulations under the Fisheries and Aquatic Resources Act No. 2 of 1996, including the High Seas Fishing Operation Regulations (2014), the Fish Catch Date Collection Regulations (2014), and the Implementation of Satellite-based VMS for Fishing Boats Operating in High Seas Regulations (2015) [76]. It now requires multi-day fishing vessels operating in high seas to install the VMS and carry a logbook onboard, whereas multi-day vessels fishing within its waters require a logbook only [98]. Additionally, Sri Lanka commenced an observer program on a pilot basis for high seas vessels (mainly for those of $24 \mathrm{~m}$ and over) in 2014 [99], in which 20 officers were trained [100]. Furthermore, Sri Lanka ratified the PSMA in 2011. It implements PSM through electronic PSM introduced by the Indian Ocean Tuna Commission (IOTC) [101].

Palau and the Federated States of Micronesia conduct regular regional surveillance operations with other FFA member States and the United States [16]. In these operations, patrol vessels of the participating countries cover a wide area of the Pacific region to detect and inspect suspicious fishing operations [102]. Such regional cooperation is conducted under the framework of the Niue Treaty and the subsequent Niue Treaty Subsidiary Agreement, which also includes the scope of information exchange through the VMS (FFA Vessel Monitoring System) [103,104]. Along with the FFA framework, the two countries receive technical assistance from their partners. The United States Coast Guard (USCG) and the respective country adopted the Permanent Shiprider Agreements, in which the surface assets of the USCG conduct enforcement operations within the EEZ of Palau/the Federates States of Micronesia on behalf of the two countries [105]. At least one officer from Palau/the Federates States of Micronesia embarks on the operations. Other technical support measures include those from Australia and the Nippon Foundation (NF). These donors have offered patrol vessels and dispatched technical advisors to both countries [106,107]. Furthermore, the NF provides funds for necessary facilities and fuels to ensure comprehensive and long-term support for the enhancement of maritime enforcement. Lastly, Palau is a party to the PSMA (signed in 2015), whereas the Federated States of Micronesia is not. However, the Federated States of Micronesia complies with the WCPFC's CMMs of PSM and applies PSM through its notification, inspection, and detection schemes [108].

Regarding existing cooperation and communication, there are already regional frameworks in place to coordinate MCS as well as fisheries management. First, the SEAFDEC actively promotes the regional cooperation of MCS in Southeast Asia. As mentioned above, it leads the capacity development program of PSM implementation for its member States. It also organized other relevant activities including the Regional Fishing Vessels Record and the ASEAN Catch Documentation Scheme [109,110]. Second, the FFA is another example of regional cooperation. As mentioned above, the Pacific countries conduct joint patrol as regional surveillance operations and share information of the VMS through the FFA Vessel Monitoring System. Third, the Bay of Bengal Programme Inter-Governmental 
Organisation (BOBP-IGO) serves as a platform to promote cooperation among the South Asian countries in fisheries management. The member States of BOBP-IGO are currently discussing preparation for the development of a RPOA-IUU [111]. As for the East Asian region, there are currently no such cooperation mechanisms.

\subsection{Effectiveness and Challenges of MCS}

The effectiveness of MCS was evidenced in some cases. For example, a study that assessed the Indonesia's countermeasures against IUU fishing shows that it resulted in a $>90 \%$ reduction in the fishing hours of foreign vessels [112]. The FFA also reported that regional surveillance was successful in deterring IUU fishing in that there was no sign of such misconduct found during the operation [113]. In contrast, MCS in Japan, particularly for coastal fisheries, did not appear to have reduced illegal fishing. While the number of fishers arrested for poaching decreased by about $80 \%$, that of non-fishing-right holders arrested rose threefold (1996-2020) [37]. Additionally, Taiwan has successfully detected and punished 227 fishing vessels with fines totaling about USD 7.2 million [41]. However, as Taiwan was listed by the United States as the IUU fishing nation in 2021 despite its MCS reform, the effectiveness of MCS is still considered a major concern [41].

Overall, it was rather difficult to assess how MCS was effective. This was largely due to the lack of time-series data available (e.g., the number of fishing vessels arrested or offenders prosecuted, the amount of fines imposed). In addition, various external factors make the assessment of MCS difficult. For example, the number of foreign vessels inspected onboard dropped sharply in 2017 and that of the vessels captured steadily declined over time in Japan (Figure 3). This trend is indeed attributed to the fact that no Chinese and Korean fishing vessels have been allowed in the EEZ of Japan since 2017 and 2016, respectively, rather than as a consequence of the increased surveillance effort [114]. Furthermore, many of the MCS measures have just been enhanced or introduced recently in most of the countries (Table 3). Therefore, additional time may be needed to detect the effectiveness of MCS.

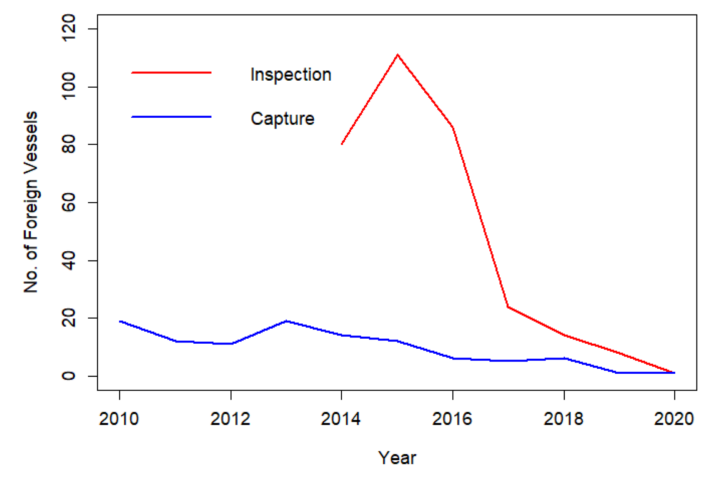

Figure 3. The number of onboard inspections and captures of foreign vessels by the Fisheries Agency of Japan (2010-2020) [115].

Regarding challenges of MCS, major challenges we identified were: (1) the limited extent and capacity of MCS (insufficient MCS measures for coastal domestic vessels and offshore foreign vessels); and (2) fragmentary coordination or cooperation between relevant agencies, stakeholders, countries, or regions. Furthermore, there was a tendency of difference in progress and capacity of MCS between coastal States of the Pacific Ocean (more advanced) and those in the Indian Ocean (less advanced).

A major challenge of MCS in Japan is the lack of effective monitoring on increased poaching in coastal areas. Another challenge is insufficient assets and human resources for adequate surveillance due to the high number of illegal foreign fishing vessels [115]. Furthermore, the rupture of the bilateral negotiations with China (since 2017) and Korea (since 2016) have resulted in pended management rules for the temporary areas set over the undetermined maritime boundaries. In Taiwan, insufficient coordination among relevant 
agencies and the lack of communication between the Fisheries Agency and fishers were mentioned as challenges of MCS (interview). These issues were said to have resulted from the rushed establishment and implementation of strict MCS measures. Additionally, increased obligations on fishers led to a backlash from them [116].

A common challenge in Indonesia and Thailand is the difficulty in monitoring and controlling small vessels because of the lack of measures and limited capacity of MCS for these vessels. The extent of vessel monitoring is limited to large vessels, resulting in low coverage of VMS requirements (Table 4), while vessel registration systems remain weak [117]. Another common challenge relates to forced labor and human trafficking associated with IUU fishing. In Thailand, the Department of Fisheries and the Ministry of Labor have collaborated to improve the legal framework of labor in the fishing industry. However, this issue remains in Thailand and Indonesia [118]. Other MCS-relevant challenges, specifically in Indonesia, include high costs of satellite imagery data, which hinder the sustainability of vessel monitoring in terms of cost efficiency. Furthermore, territorial disputes between Indonesia and China inhibit MCS of IUU fishing. In spite of its success in reducing IUU fishing, Indonesia is now said to have toned down its coercive actions against foreign fishing vessels (e.g., burning illegal fishing vessels) due partly to diplomatic reasons with regional countries including China (expert's comment).

Compared to other countries, the extent of MCS implementation is less advanced in Bangladesh and Sri Lanka. Bangladesh has introduced the VMS to commercial fishing vessels in recent years, but the Fisheries Monitoring Center (FMC) to coordinate VMS data is still under development. The FMC of Sri Lanka, on the other hand, covers multi-day vessels operating in high seas, but does not cover the remaining multi-day vessels fishing in Sri Lankan EEZ (which accounts for about $75 \%$ of such vessels) [26]. Furthermore, the coverage of vessel tracking is low in both countries despite weak vessel registration systems (Table 4) [117]. Sri Lanka also faces the issue of observer coverage set under IOTC Resolution 10/04 [100,119]. All its high sea vessels but one are less than $24 \mathrm{~m}$, and because of the limited capacity of the vessels for extra crews, it is not practical to send observers onboard [99]. Another common challenge is that Bangladesh and Sri Lanka lack coordination with neighboring countries. There has been an attempt to foster cooperation among the countries in the Bay of Bengal region (e.g., BOBP-IGO). However, there is still a high number of encroachments by foreign fishing vessels. The reason behind this, especially for Sri Lanka, is the difference in the historical perception of ocean use between its fishers and fishers from the neighboring country. Fishers from Tamil Nadu of India have long been fishing in the north of Sri Lanka and claim a traditional right to fish there [59].

Table 4. The total number of vessels, and the number and percentage of vessels required to install the VMS in the five countries (Japan, Indonesia, Thailand, Bangladesh, and Sri Lanka).

\begin{tabular}{cccc}
\hline Country & Total No. of Vessels & $\begin{array}{c}\text { No. of Vessels } \\
\text { Required to Install } \\
\text { VMS }\end{array}$ & $\begin{array}{c}\text { Percentage of Vessels } \\
\text { Required to Install VMS }\end{array}$ \\
\hline Japan & $123,120[120]$ & $1256[121]$ & 1.02 \\
\hline Indonesia & $568,239[47]$ & $2840[47]$ & 0.50 \\
\hline Thailand & $42,512[48]$ & $4675[122]$ & $11.00^{\text {a }}$ \\
\hline Bangladesh & $48,976[25]$ & $1189[25]$ & 2.43 \\
\hline Sri Lanka & $67,922[26]$ & $253[26]$ & 0.37 \\
\hline
\end{tabular}

Note: ${ }^{\text {a }}$ The figure calculated was based on information taken from different years with the total number of vessels in 2015 and the number of vessels required to install the VMS (vessels of 30 gross tons or over) in 2020.

A major challenge that Palau and the Federated States of Micronesia face is the lack of assets and human resources for MCS. Despite the vast ocean areas to manage, the capacity of the two countries to adequately conduct MCS is limited. There are only a few patrol vessels possessed by these countries, making it difficult to detect illegal fishing vessels at 
sea. To improve MCS capacity, Palau has consulted with international NGOs to implement a satellite imagery data system [123]. However, the system has not yet been introduced because of the cost that Palau had to bear. In relation to onboard observers, the low observer coverage of longline fishing vessels is considered a challenge among the Parties of the Nauru Agreement (PNA), including the two aforementioned countries (a minimum requirement of $5 \%$ for longline vessels in the WCPFC area is necessary) $[124,125]$. To solve this issue, the parties are discussing electronic monitoring systems. Additionally, PNA requires $100 \%$ coverage of observers for purse seine vessels, but the COVID-19 pandemic has made it difficult to achieve this requirement [126]. Furthermore, Palau faces a shortage of human resources in the implementation of PSM. The Offshore Fisheries Section of the Bureau of Marine Resources is now in charge of PSM, but Palau has no agency specifically established in order to control domestic ports (interview).

\section{Discussion}

The conditions of IUU fishing are linked to the status of fisheries [127]. In this study, we confirmed that there were several conditions of IUU fishing, depending on the status of fisheries in each country. For example, domestic fishing vessels are more likely to be a major cause of IUU fishing in DWF countries. In contrast, IUU fishing by foreign vessels may be more rampant in countries where such vessels are allowed in their EEZs. Careful consideration is required for such differences (domestic vessels vs. foreign vessels) in the implementation of MCS, as it determines priorities in the flag or coastal States [128].

Regarding foreign vessels, we reported that there were illegal activities by: (1) unlicensed vessels (e.g., blue boats); and (2) legitimate vessels (e.g., licensed vessels that do not appropriately report catch). The blue boats do not usually carry an active VMS; therefore, enhancement of visual surveillance is required to detect such vessels. In contrast, legitimate vessels may be detected through their VMS, but further investigation (e.g., observers, port inspection) is needed to ensure that they do not conduct IUU fishing.

As for domestic vessels, we confirmed two major actors of IUU fishing; smallscale/artisanal fishers in coastal areas and large-scale/commercial fishers in offshore areas. There may be different motivations or socioeconomic drivers of IUU fishing, depending on actors of this misconduct. For example, commercial fishers may do so for economic incentives (e.g., minimizing costs by evading rules) [129]. One study also discusses that two factors (the number of commercially important species and the proximity of ports of convenience) can increase a risk of IUU fishing, mainly in offshore and distant water fisheries [130]. In contrast, fishers in coastal areas may be driven to poach for need (e.g., financial necessities, poverty, long-term unemployment) or just for selfconsumption [131,132]. Other reasons include a political act of fishers to express their opposition against newly introduced regulations when they deem it unreasonable [133], or simply the lack of awareness among them [134]. Strong law enforcement should be a primary solution to combat IUU fishing in any type of fishery [135]. Simultaneously, more socioeconomic approaches may be required for small-scale artisanal fisheries (e.g., poverty eradication) in order to address complex drivers of IUU fishing among them [136,137]. Appropriate MCS measures can be determined by who commits IUU fishing; thus, each country should implement suitable measures according to the characteristics of IUU fishing.

Depending on the conditions of IUU fishing, each country takes a variety of MCS measures with different emphases. We also confirmed that various measures had been enhanced or newly established in the eight countries over the past decade, but with four focal areas: (1) vessel tracking; (2) patrol; (3) onboard observers; and (4) PSM. These measures are supported by new or amended laws and regulations. The rapid development of MCS enhancement over the past decade can be attributed to increasing awareness of the importance of sustainable fisheries management (e.g., SDGs) [138]. The growing threat of overfishing by both domestic and foreign fishing vessels may have been another driver [139]. 
First, the VMS is a useful tool for vessel tracking, employed in many of the fishing countries [140,141]; however, there are still some challenges to address. We found that the VMS coverage set under the current laws or regulations was partial (only to offshore and DWF vessels) (Table 2). The actual coverage is possibly even lower due to several difficulties (e.g., high cost of the VMS [98]), and it may vary among the countries depending on their capacity. As such, enhancement of visual surveillance is key to fulfilling geographical gaps in MCS (especially in coastal areas) [142]. The challenge of vessel tracking also emphasizes the need for an enhanced vessel registration system to improve vessel control. We also found differences in regulations of the VMS among the eight countries. VMS regulations are usually set up to cover the minimal requirements of the VMS stipulated in CMMs of the RFMOs, but these regulations are indeed inconsistent even among parties of the same RFMO. Therefore, inconsistency in VMS regulations may cause confusion between the flag and coastal States. Frequent communication about VMS regulations among these States (when inconsistency in regulations causes confusion) can be useful to ensure coordination and harmonization among the countries in vessel monitoring.

Second, enhancement of patrols is a fundamental component to strengthen MCS as illegal fishery products originate from fishing vessels at sea [130]. We presented that several countries of the Asia-Pacific had enhanced patrols by establishing a new agency, coordinating with other agencies, or collaborating with regional countries. Identified challenges include insufficient assets and human resources (especially for coastal domestic vessels and offshore foreign vessels). We therefore suggest recommendations with two levels: within and among countries. At the national level, collaboration among different stakeholders is key. For example, working with fishers for co-monitoring and with private sectors for the utilization of novel technologies are potential approaches to strengthen MCS in coastal areas $[8,143]$. The improvements in awareness of MCS and frequent communication among stakeholders should also be accompanied to promote such collaboration [144]. Additionally, seamless interagency coordination (e.g., through information sharing) among relevant agencies, as is done by the THAI-MECC of Thailand, is needed for effective vessel control and monitoring [145]. At the multilateral level, cross-border cooperation is imperative to manage offshore areas as demonstrated in joint surveillance by the FFA. It is especially necessary for Asian countries where EEZs are next to each other and where vessels often stray into the EEZs of neighboring countries.

Third, onboard observers can provide an effective tool to directly monitor fishing activities [129]. The eight countries, except Palau, deploy observers under the RFMOs. However, the limited space of fishing vessels for extra crews and the low coverage of observers ( $5 \%$ requirement for longline vessels in the WCPFC) have been reported as challenges, as mentioned above. Other challenges include the high cost of training observers and difficulty in securing their safety onboard $[146,147]$. Electronic monitoring is being discussed as an alternative, although this system itself has some issues to resolve (e.g., cost) $[148,149]$. Financial and technical assistance would be required in the initial stage of implementing electronic monitoring and long-term follow-up to maintain it.

Fourth, PSM is considered a cost-effective and efficient means of controlling IUU fishing vessels [150]. The eight countries are parties to the PSMA or non-parties, but take PSM through their own national schemes. PSM is a relatively new MCS measure, and implementation capacity may vary among countries depending on their starting year. A network of MCS covering the Asia-Pacific can be useful to exchange experience and lessons learned, and to promote capacity building as exemplified in the regional cooperation in PSM by the SEAFDEC. Moreover, coordination between the two measures (monitoring vessels through visual surveillance by the coastal States and controlling vessels through port inspection by the port States) can increase the overall effectiveness of MCS.

Although the eight countries have made significant efforts on MCS in the past 10 years, there was little evidence of how such effort was effective. In addition, various external factors that affect the consequence of MCS efforts make the assessment of MCS difficult (e.g., rupture of the bilateral agreements on fisheries). We see the lack of information as 
a researchers' challenge. Considering complex situations of IUU fishing and a paucity of resources, however, it is also the countries' challenge to assess the effectiveness of MCS. In any case, countries should start considering how to evaluate MCS to ensure that their efforts contribute to deterring IUU fishing. The cost-benefit analysis of MCS can also be useful as exemplified by FAO in Sri Lanka [100]. In addition, making a protocol for the assessment of MCS effectiveness may help standardize the evaluation process.

In addition to challenges in each MCS measure, we identified fragmented coordination and cooperation within and between the countries as another major challenge [8]. There was also a tendency of less developed MCS in the two Indian Ocean countries (Bangladesh and Sri Lanka) compared to the Pacific Ocean countries. This case can be applied to other countries in the Indian Ocean area owing to various factors they are experiencing (e.g., civil war, piracy [151,152]). As discussed above, coordination among relevant agencies and collaboration among stakeholders within the country are essential to improve the effectiveness of MCS. Enhancement of multilateral cooperation is also important, especially between the flag and coastal States within a region (e.g., Southeast Asian region, South Asian regions, etc.). Especially, East Asia is the only region in the Asia-Pacific where the regional cooperation mechanism is absent. Thus, the countries in this region may discuss possibility of such a mechanism. Furthermore, cooperation at an "inter-regional level" is needed to solve conflicts between the flag and coastal States when they belong to different regions (e.g., Southeast Asian countries as the flag States and Pacific countries as the coastal States) and to address regional discrepancies in MCS capacity within the Asia-Pacific (i.e., between Pacific Ocean and Indian Ocean countries).

Enhanced, coordinated efforts on MCS should be accompanied with addressing motivation of IUU fishing offenders, especially for domestic small-scale/artisanal fishers. The formal MCS or anti-IUU measures we presented in this study (e.g., VMS) are punitive, and they are not necessarily adapted to the socioeconomic context of each unique IUU fishing case. To address a gap in the current MCS mechanisms, the countries need to carefully assess the institutional framework of each fishery, and identify and address root causes of IUU fishing $[131,137]$. The socioeconomic approach could supplement the current MCS which would otherwise be insufficient to solve the issue of IUU fishing.

Based on our findings, we propose a communication platform for MCS to promote cooperation between the countries and regions for MCS enhancement. This platform can be established through building a network of existing regional cooperation mechanisms including the SEAFDEC, FFA, and BOBP-IGO, as well as RFMOs. It can also be in the form of a clearing house mechanism to exchange information of the following: (1) needs for technical cooperation; (2) possible technical cooperation menus; and (3) lessons learned from MCS and other solutions to IUU fishing (e.g., how the countries have tackled IUU fishing through MCS activities or what kind of socioeconomic approaches they have taken). Enhanced MCS can increase the recovery rate from economic loss caused by IUU fishing [153], and can be an effective tool to minimize short-term reduction in fishing efforts for resource recovery [112]. All States are now urged to strengthen coordination and cooperation toward the achievement of Target 14.4 in SDG14: putting an end to IUU fishing.

Author Contributions: Conceptualization, I.F.; investigation, I.F., Y.O. and H.K.; writing—original draft preparation, I.F.; writing-review and editing, Y.O. and H.K. All authors have read and agreed to the published version of the manuscript.

Funding: This research received no external funding.

Institutional Review Board Statement: Ethical review and approval were waived for this study, due to following reason: the purpose of the interview in this study is to confirm the accuracy of information collected from publicly available sources rather than to obtain personal or confidential information from the specific persons or organizations.

Informed Consent Statement: Informed consent was obtained from all subjects involved in the study. 
Data Availability Statement: Not applicable.

Acknowledgments: The authors acknowledge all members of the Ocean Policy Research Institute of the Sasakawa Peace Foundation and Japan NUS Co., Ltd., for collecting information, providing useful advice, and contributing to our discussion to improve the manuscript. We would also like to express our gratitude to Mitsutaku Makino at the Atmosphere and Ocean Research Institute of the University of Tokyo for his useful inputs.

Conflicts of Interest: The authors declare no conflict of interest.

\section{Appendix A}

List of items asked to confirm the accuracy of collected information in the interview.

(1) MCS using patrol vessels and its problems or difficulties in (the interviewed country)

(2) MCS using VMS/AIS and its problems or difficulties in (the interviewed country)

(3) Laws or regulations of MCS in (the interviewed country)

(4) IUU-related regulations such as the National Plan of Action in (the interviewed country)

(5) Other IUU-related measures or policies in (the interviewed country)

(6) Situations of IUU fishing and awareness of this issue in (the interviewed country)

(7) Necessity of new cooperation on IUU fishing in the Indo-Pacific region

\section{Appendix B}

List of institutions interviewed in the eight Asia-Pacific countries.
(1) Japan: Fisheries Agency
(2) Taiwan: National Academy of Marine Research
(3) Indonesia: Institute for Marine Research and Observation
(4) Thailand: Department of Fisheries
(5) Bangladesh: Department of Fisheries
(6) Sri Lanka: Department of Fisheries and Aquatic Resources
(7) Palau: Bureau of Marine Resources
(8) Federated States of Micronesia: National Oceanic Resource Management Authority

\section{Appendix C}

List of fisheries permitted by the Minister of Agriculture, Forestry and Fisheries.
(1) Offshore trawl fishery
(2) East China Sea trawl fishery
(3) Distant water trawl fishery
(4) Large and medium-scale purse seine fishery
(5) Base type whale fishery
(6) Mother ship type whale fishery
(7) Skipjack/tuna fishery
(8) Medium-scale salmon driftnet fishery
(9) North Pacific Ocean saury fishery
(10) Sea of Japan red snow crab fishery
(11) Squid jigging fishery
(12) East China Sea longline fishery
(13) Atlantic Ocean longline fishery
(14) Pacific Ocean bottom gillnet fishery
(15) Marline etc. drift net fishery
(16) East China Sea marline etc. drift net fishery
(17) Red snow crab fishery 


\section{References}

1. Agnew, D.J.; Pearce, J.; Pramod, G.; Peatman, T.; Watson, R.; Beddington, J.R.; Pitcher, T.J. Estimating the worldwide extent of illegal fishing. PLoS ONE 2009, 4, e4570:1. [CrossRef]

2. Food and Agriculture Organization of the United Nations. The State of World Fisheries and Aquaculture 2020. Available online: http:/ / www.fao.org/3/ca9229en/ ca9229en.pdf (accessed on 14 July 2021).

3. Flothmann, S.; von Kistowski, K.; Dolan, E.; Lee, E.; Meere, F.; Album, G. Closing loopholes: Getting illegal fishing under control. Science 2010, 328, 1235-1236. [CrossRef] [PubMed]

4. Food and Agriculture Organization of the United Nations. Asia-Pacific Revenues and Livelihoods Threatened as Billions Lost Annually to Illegal, Unreported, Unregulated Fishing-UN FAO. Available online: http:/ / www.fao.org/asiapacific/news /detailevents/en/c/1196430/ (accessed on 14 July 2021).

5. Donlan, C.J.; Wilcox, C.; Luque, G.M.; Gelcich, S. Estimating illegal fishing from enforcement officers. Sci. Rep. 2020, 10, 1-9. [CrossRef]

6. Food and Agriculture Organization of the United Nations. Illegal, Unreported and Unregulated (IUU) Fishing. Available online: http:/ / www.fao.org/iuu-fishing/background/what-is-iuu-fishing/en/ (accessed on 14 July 2021).

7. Aceves-Bueno, E.; Read, A.J.; Cisneros-Mata, M.A. Illegal fisheries, environmental crime, and the conservation of marine resources. Conserv. Biol. 2020, 35, 1120-1129. [CrossRef]

8. Lindley, J.; Techera, E.J. Overcoming complexity in illegal, unregulated and unreported fishing to achieve effective regulatory pluralism. Mar. Policy 2017, 81, 71-79. [CrossRef]

9. Food and Agriculture Organization of the United Nations. International Plan of Action to Prevent, Deter, and Eliminate Illegal, Unreported and Unregulated Fishing. Available online: http:/ / www.fao.org/3/y1224e/Y1224E.pdf (accessed on 14 July 2021).

10. Food and Agriculture Organization of the United Nations. Agreement on Port State Measures (PSMA). Available online: http:/ / www.fao.org/port-state-measures/en/ (accessed on 14 July 2021).

11. United Nations Department of Economic and Social Affairs. Goal 14. Available online: https://sdgs.un.org/goals/goal14. (accessed on 14 July 2021).

12. RPOA-IUU. Home. Available online: https://www.rpoaiuu.org/ (accessed on 14 July 2021).

13. Davis, R.A.; Hanich, Q. Transparency in fisheries conservation and management measures. Mar. Policy 2020, 104088. [CrossRef]

14. European Union. COUNCIL REGULATION (EC) No 1005/2008 of 29 September 2008 Establishing a Community System to Prevent, Deter and Eliminate Illegal, Unreported and Unregulated Fishing, Amending Regulations (EEC) No 2847/93, (EC) No 1936/2001 and (EC) No 601/2004 and Repealing Regulations (EC) No 1093/94 and (EC) No 1447/1999. Available online: https: / / eur-lex.europa.eu/legal-content/EN/TXT/?uri=CELEX:32008R1005 (accessed on 14 July 2021).

15. Saraphaivanich, K.; Suthipol, Y.; Imsamrarn, N. Strengthening regional cooperation to support the implementation of port state measures in Southeast Asia. Fish People 2017, 15, 17-22.

16. Pacific Islands Forum Fisheries Agency. Regional Surveillance Operations. Available online: https://www.ffa.int/regional_ operations (accessed on 14 July 2021).

17. Southeast Asian Fisheries Development Center. The Southeast Asian State of Fisheries and Aquaculture 2017. Available online: http:/ / www.seafdec.org/download/southeast-asian-state-fisheries-aquaculture-2017/ (accessed on 14 July 2021).

18. Yleaña, J.S.; Velasco, P.E.L. Monitoring, Control and Surveillance (MCS) in Southeast Asia: Review of the Establishment of Regional MCS Network. Fish People 2012, 10, 7-12.

19. Shen, H.; Huang, S. China's policies and practice on combatting IUU in distant water fisheries. Aquac. Fish. 2021, 6, 27-34. [CrossRef]

20. Kim, H.J. Inducing state compliance with international fisheries law: Lessons from two case studies concerning the Republic of Korea's IUU fishing. Int Environ Agreements 2019, 19, 631-645. [CrossRef]

21. Desierto, D. China's Maritime Law Enforcement Activities in the South China Sea. Int. Law Stud. 2020, 96, $257-273$.

22. Mongabay. China Issues New Sustainability Rules for its Notorious Fishing Fleet. Available online: https://news.mongabay. com/2020/08/china-issues-new-sustainability-rules-for-its-notorious-fishing-fleet/ (accessed on 26 August 2021).

23. Chang, Y.C.; Li, X. The disappearance of the State Oceanic Administration in China?-Current developments. Mar. Policy 2019, 107, 103588. [CrossRef]

24. Food and Agriculture Organization of the United Nations. Asia-Pacific Fishery Commission (APFIC). Available online: http: / / www.fao.org/asiapacific/apfic/en/ (accessed on 14 July 2021).

25. Department of Fisheries, Bangladesh. Annual Report 2018. Available online: http://fisheries.gov.bd/sites/default/files/files/ fisheries.portal.gov.bd/annual_reports/e0400ef4_6fd3_434b_aa94_0333d5f4c4c8/2020-06-28-13-32-95cad3eec7f0aeb717ae432 01c6ea1c9.PDF (accessed on 14 July 2021).

26. Ministry of Fisheries and Aquatic Resources Development, Sri Lanka. Fisheries Statistics 2020. Available online: https://www. fisheriesdept.gov.lk/web/images/Statistics/FISHERIES-STATISTICS--2020-.pdf (accessed on 14 July 2021).

27. National Environmental Protection Council, Palau. 2019 State of the Environment Report, Republic of Palau. Available online: https: / / palau-data.sprep.org/system/files/2019-Palau-SOE-FINAL-6-24-2020-EDITED.pdf (accessed on 14 July 2021).

28. National Oceanic Resource Management Authority, the Federated States of Micronesia. Annual Report 2017-2019. Available online: https:/ / www.norma.fm/wp-content/uploads/2021/06/NORMA-Annual-Report-2017-2019-FINAL.pdf (accessed on 14 July 2021). 
29. Mackay, M.; Hardesty, B.D.; Wilcox, C. The intersection between illegal fishing, crimes at sea, and social well-being. Front. Mar. Sci. 2020, 7, 589000. [CrossRef]

30. Beseng, M. Cameroon's choppy waters: The anatomy of fisheries crime in the maritime fisheries sector. Mar. Policy 2019, 108, 103669. [CrossRef]

31. Bergseth, B.J.; Roscher, M. Discerning the culture of compliance through recreational fisher's perceptions of poaching. Mar. Policy 2018, 89, 132-141. [CrossRef]

32. Ruddle, K.; Segi, S. The management of inshore marine recreational fishing in Japan. Coast. Manag. 2006, 34, 87-110. [CrossRef]

33. Derrick, B.; Noranarttragoon, P.; Zeller, D.; Teh, L.C.; Pauly, D. Thailand's missing marine fisheries catch (1950-2014). Front. Mar. Sci. 2017, 4, 402. [CrossRef]

34. STIMSON. Shining a Light: The Need for Transparency across Distant Water Fishing. Available online: https:/ /www.stimson. org/wp-content/files/file-attachments/Stimson\%20Distant\%20Water\%20Fishing\%20Report.pdf (accessed on 14 July 2021).

35. Fisheries Agency, Japan. Reiwa Gan-nen Suisan Hakusho [Fisheries White Paper 2019] (in Japanese). Available online: https: / / www.jfa.maff.go.jp/j/kikaku/wpaper/R1/attach/pdf/index-2.pdf (accessed on 14 July 2021).

36. Fisheries Agency, Japan. Heisei Nijukyu-nen Suisan Hakusho [Fisheries White Paper 2017] (in Japanese). Available online: https://www.jfa.maff.go.jp/j/kikaku/wpaper/h29_h/trend/1/t1_2_3_6.html (accessed on 14 July 2021).

37. Fisheries Agency, Japan. Mitsuryo o Yurusanai Suisan-cho no Mitsuryo Taisaku [We don't tolerate poaching $\sim$ Countermeasures against Poaching by the Fisheries Agency ] (in Japanese). Available online: https://www.jfa.maff.go.jp/j/enoki/mitsuryotaisaku. html\#: \{\}:text=\%E5\%B9\%B3\%E6\%88\%9030\%E5\%B9\%B4\%E3\%81\%AE\%E5\%85\%A8\%E5\%9B\%BD,\%E3\%81\%8C\%E5\%A2\%97\% E5\%8A $\%$ A0\%E5\%82\%BE\%E5\%90\%91\%E3\%81\%AB\%E3\%81\%82\%E3\%82\%8A\%E3\%81\%BE\%E3\%81\%99\%E3\%80\%82 (accessed on 14 July 2021).

38. Department of Justice, the United States. Owner of Japanese Fishing Vessel Charged with Unlawful Trafficking of Shark Fins. Available online: https://www.justice.gov/opa/pr/owner-japanese-fishing-vessel-charged-unlawful-trafficking-shark-fins (accessed on 14 July 2021).

39. Fisheries Agency, Japan. Reiwa San-nen Gyogyo Torishimari Hoshin [Fisheries Surveillance Policy in 2021] (in Japanese). Available online: https://www.jfa.maff.go.jp/j/kanri/torishimari/attach/pdf/R3_torishimari_houshin.pdf (accessed on 14 July 2021).

40. The Republic of China. Laws and Regulations Database of the Republic of China "Act for Distant Water Fisheries". Available online: https: / /law.moj.gov.tw / ENG/LawClass/LawAll.aspx?pcode=M0050051 (accessed on 14 July 2021).

41. Huang, C.C.; Chang, S.K.; Shyue, S.W. Sustain or phase out: Transformation of Taiwan's management scheme on distant water tuna longline fisheries. Mar. Policy 2021, 123, 104297. [CrossRef]

42. International Commission for the Conservation of Atlantic Tunas. REPORT for Biennial Period, 2004-2005 PART II (2005)—Vol. 1 English version. Available online: https:/ / www.iccat.int/Documents / BienRep/REP_EN_04-05_II_1.pdf (accessed on 14 July 2021).

43. Chen, C.L. Taiwan's response to international fisheries management after 2005 as influenced by ICCAT and fishers' perception. Mar. Policy 2012, 36, 350-357. [CrossRef]

44. Fisheries Agency, Taiwan. Alleged Violations from F/V Shuen De Ching No.888, Escorted by Taiwan Patrol Vessel for Sailing back to Taiwan for Further Investigation and Punishment. Available online: https://www.fa.gov.tw/en/Announcement/content. aspx?id=41\&chk=427890bc-4251-4e75-83fd-d6de4d03ac4d (accessed on 14 July 2021).

45. European Parliament. Illegal, Unreported and Unregulated (IUU) Fishing. Available online: https: / www.europarl.europa.eu/ RegData/etudes/ATAG/2017/614599/EPRS_ATA(2017)614599_EN.pdf (accessed on 14 July 2021).

46. Taiwan News. Taiwanese Fishing Boat Detained in Indonesia for Illegal Fishing. Available online: https:/ / www.taiwannews. com.tw/en/news/4110066 (accessed on 14 July 2021).

47. Southeast Asian Fisheries Development Center. Fisheries Country Profile: Indonesia. Available online: http://www.seafdec.org/ fisheries-country-profile-indonesia / (accessed on 14 July 2021).

48. Department of Fisheries, Thailand. Marine Fisheries Management Plan of Thailand. Available online: http:/ / extwprlegs1.fao org/docs/pdf/tha165156.pdf (accessed on 14 July 2021).

49. Sodik, D.M. Analysis of IUU fishing in Indonesia and the Indonesian legal framework reform for monitoring, control and surveillance of fishing vessels. Int. J. Mar. Coast. Law 2009, 24, 67-100. [CrossRef]

50. McWilliam, A.R.; Wianti, N.I.; Taufik, Y. Poverty and prosperity among Sama Bajo fishing communities (Southeast Sulawesi, Indonesia). Singap. J. Trop. Geogr. 2021, 42, 132-148. [CrossRef]

51. Chapsos, I.; Hamilton, S. Illegal fishing and fisheries crime as a transnational organized crime in Indonesia. Trends Organ. Crim. 2019, 22, 255-273. [CrossRef]

52. Vandergeest, P.; Tran, O.; Marschke, M. Modern day slavery in Thai fisheries: Academic critique, practical action. Crit. Asian Stud. 2017, 49, 461-464. [CrossRef]

53. Meyer, P.K.; Nurmandi, A.; Agustiyara, A. Indonesia's swift securitization of the Natuna Islands how Jakarta countered China's claims in the South China Sea. Asian J. Political Sci. 2019, 27, 70-87. [CrossRef]

54. Pramod, G. Global Evaluation of Fisheries Monitoring Control and Surveillance in 84 countries, Bangladesh-Country Report. Available online: https:/ /iuuriskintelligence.com/wp-content/uploads/2021/05/Bangladesh-country-Report-Global-FisheriesMCS-Report-2020.pdf (accessed on 14 July 2021). 
55. World Bank. Bangladesh Sustainable Coastal and Marine Fisheries. Available online: http://documents1.worldbank.org/ curated/en/308831538969417996/pdf/Bangladesh-Sustainable-Coastal-and-Marine-Fisheries-PAD-P161568-2-09182018.pdf (accessed on 14 July 2021).

56. Karunathilaka, S.R.; Bandara, H.R.L.C.; Manikarachchi, M.I.U. Illegal Unreported Unregulated Fishing by Sri Lankan Fishermen: Law Implementation Mechanism and Fishers' Attitudes on Compliance. Available online: http://ir.kdu.ac.lk/handle/345/1734 (accessed on 14 July 2021).

57. Collins, C.; Nuno, A.; Benaragama, A.; Broderick, A.; Wijesundara, I.; Wijetunge, D.; Letessier, T.B. Ocean-scale footprint of a highly mobile fishing fleet: Social-ecological drivers of fleet behaviour and evidence of illegal fishing. People Nat. 2021, 3, 740-755. [CrossRef]

58. Shamsuzzaman, M.M.; Islam, M.M. Analysing the legal framework of marine living resources management in Bangladesh: Towards achieving Sustainable Development Goal 14. Mar. Policy 2018, 87, 255-262. [CrossRef]

59. Kularatne, R.K.A. Unregulated and illegal fishing by foreign fishing boats in Sri Lankan waters with special reference to bottom trawling in northern Sri Lanka: A critical analysis of the Sri Lankan legislation. Ocean. Coast. Manag. 2020, 185, 105012. [CrossRef]

60. The Parties to the Nauru Agreement. The PNA Vessel Day Scheme. Available online: https://www.pnatuna.com/content/pnavessel-day-scheme (accessed on 14 July 2021).

61. Oleson, K.; Dacks, R.; Lewis, S.; Ferrini, S.; Fezzi, C. Palau National Marine Sanctuary-Socioeconomic Baseline Project. Available online: https:/ / picrc.org/picrcpage/wp-content/uploads/2019/05/Oleson-PNMS-Socioeconomic-2019-2.pdf (accessed on 14 July 2021).

62. National Oceanic Resource Management Authority, the Federated States of Micronesia. Activities Inside the FSM EEZ. Available online: http: / / www.norma.fm/activities-inside-the-fsm-eez/ (accessed on 14 July 2021).

63. Pew Charitable Trust. The Republic of Palau Exclusive Economic Zone, MONITORING, CONTROL, AND SURVEILLANCE, The Next Five Years, 2016-2021. Available online: https:/ / www.pewtrusts.org/-/media/assets/2016/05/palau_monitoring_ control_and_surveillance.pdf (accessed on 14 July 2021).

64. Song, A.M.; Hoang, V.T.; Cohen, P.J.; Aqorau, T.; Morrison, T.H. 'Blue boats' and 'reef robbers': A new maritime security threat for the Asia Pacific? Asia Pac. Viewp. 2019, 60, 310-324. [CrossRef]

65. Secretariat of the Pacific Regional Environmental Programme. Federated States of Micronesia State of Environment Report 2018. Available online: https://www.sprep.org/sites/default/files/documents/publications/fsm-soe.pdf (accessed on 14 July 2021).

66. MRAG Asia Pacific. Towards the Quantification of Illegal, Unreported and Unregulated (IUU) Fishing in the Pacific Islands Region. Available online: https:/ / www.ffa.int/files/FFA\%20Quantifying\%20IUU\%20Report\%20-\%20Final.pdf (accessed on 14 July 2021).

67. Government of Japan. Japanese Law Translation "Fishery Act, Law Number: Act No 267 of 1949 ". Available online: http: / / www.japaneselawtranslation.go.jp $/$ law $/$ detail $/$ ? $\mathrm{ft}=1 \& \mathrm{re}=01 \& \mathrm{dn}=1 \& \mathrm{x}=0 \& \mathrm{y}=0 \& \mathrm{co}=01 \& \mathrm{ia}=03 \& \mathrm{ja}=04 \& \mathrm{ky}=\% \mathrm{E} 6 \% \mathrm{BC} \% 81$ $\% \mathrm{E} 6 \% \mathrm{~A} 5 \% \mathrm{AD} \% \mathrm{E} 6 \% \mathrm{B3} \% 95 \&$ page $=4$ (accessed on 14 July 2021).

68. Government of Japan. Japanese Law Translation “Ministerial Ordinance on the Permission, Regulation, Etc. of Designated Fisheries". Available online: http: / $/$ www.japaneselawtranslation.go.jp $/$ law $/$ detail $/$ ? $\mathrm{re}=01 \& \mathrm{dn}=1 \& \mathrm{x}=0 \& \mathrm{y}=0 \& \mathrm{co}=1 \& \mathrm{a} \mathrm{a}=03 \& \mathrm{ja}=$ 04\&yo=\&gn=\&sy=\&ht=\&no=\&bu=\&ta=\&ky=\%E6\%BC\%81\%E6\%A5\%AD \%E3\%81\%AE \%E8\%A8\%B1\%E5\%8F\%AF\%E5\%8F\% 8A $\%$ E3\%81\%B3\%E5\%8F\%96\%E7\%B7\%A0\%E3\%82\%8A\%E7\%AD\%89\%E3\%81\%AB\%E9\%96\%A2\%E3\%81\%99\%E3\%82\%8B\% E7\%9C $\% 81 \% \mathrm{E} 4 \% \mathrm{BB} \% \mathrm{~A} 4 \&$ page $=3$ (accessed on 14 July 2021).

69. The Republic of China. Laws and Regulations Database of the Republic of China "Regulations on the Management and Guidance of the Equipment for Vessel Position Reporting, Catch Reporting, Navigational Chart, and Monitoring Center". Available online: https: / /law.moj.gov.tw / ENG/LawClass/LawAll.aspx?pcode=M0050053 (accessed on 14 July 2021).

70. Food and Agricultural Organization of the United Nations. Regulation of the Minister of Marine and Fisheries of the R.I. No. 42/Permen-Kp/2015 about Fishing Vessel Monitoring System. Available online: http:/ / extwprlegs1.fao.org/docs/pdf/ins17888 5.pdf (accessed on 14 July 2021).

71. Ikrami, H. Indonesia's Reform of Its Fisheries Law and Policy \& Cooperation with ASEAN in Combating IUU Fishing. Asia-Pac. J. Ocean. Law Policy 2017, 2, 318-330. [CrossRef]

72. Department of Fisheries of Thailand. Law and Regulation. Available online: https://www4.fisheries.go.th/dof_en/view_ message/224 (accessed on 14 July 2021).

73. Department of Fisheries, Thailand. The National Plan of Action to Prevent, Stop, and Eliminate IUU Fishing. Available online: http:/ / www.fao.org/faolex/results/details/en/c/LEX-FAOC169693/ (accessed on 9 September 2021).

74. Department of Fisheries, Thailand. Standard Operating Procedure Foreign Flags Vessel Control and Inspection under Port State Measures (PSM). Available online: https://www4.fisheries.go.th/local/file_document/20171114131523_1_file.pdf (accessed on 14 July 2021).

75. Food and Agricultural Organization of the United Nations. Fisheries and Aquatic Resources Act 1996, No. 2 of 1996. Available online: http:/ / extwprlegs1.fao.org/docs/pdf/srl4092.pdf (accessed on 14 July 2021).

76. Department of Fisheries and Aquatic Resources, Sri Lanka. Collection of High Seas Fishing Legislations of Sri Lanka. Available online: https:/ / www.fisheriesdept.gov.lk/web/images / pdf/regulations/collection_of_high_seas_regulations1.pdf (accessed on 14 July 2021). 
77. Food and Agricultural Organization of the United Nations. Palau National Marine Sanctuary Act (RPPL No. 9-49 of 2015). Available online: http:/ / extwprlegs1.fao.org/docs/pdf/pau152765.pdf (accessed on 14 July 2021).

78. Government of the Federated States of Micronesia. FSMC, TITLE 24. MARINE RESOURCES. Available online: http:/ fsmlaw. org/fsm/code/title24/T24_Ch6_2014.html (accessed on 14 July 2021).

79. Government of the Federated States of Micronesia. National Plan of Action to prevent, Deter and Eliminate Illegal, Unreported and Unregulated fishing.

80. Fisheries Agency, Japan. Gyogyo Torishimari Honbu no Secchi ni Tsuite [Regarding the Establishment of the Fisheries Surveillance Headquarters] (in Japanese). Available online: https://www.jfa.maff.go.jp/j/kanri/torishimari/attach/pdf/torishimari2-3.pdf (accessed on 14 July 2021).

81. Western and Central Pacific Fisheries Commission. Authorised ROP Observer Providers. Available online: https://www.wcpfc. int/authorised-rop-observer-providers (accessed on 14 July 2021).

82. Fisheries Agency, Japan. Gaikoku Gyosen ni Taisuru Kisei ni Kansuru Joho [Information of Regulations of Foreign Fishing Vessels] (in Japanese). Available online: https://www.jfa.maff.go.jp/j/kanri/kikokyoka/kikokyoka.html (accessed on 14 July 2021).

83. Tai, T.H.; Kao, S.M.; Ho, W.C. International Soft Laws against IUU Fishing for Sustainable Marine Resources: Adoption of the Voluntary Guidelines for Flag State Performance and Challenges for Taiwan. Sustainability 2020, 12, 6013. [CrossRef]

84. Council of Agriculture, Executive Yuan Republic of China. Entry into Force of Three Distant Water Fisheries Related Laws Requiring Industry's Full Compliance. Available online: https:/ / eng.coa.gov.tw / theme_data.php?theme=eng_news\&id=480\& print $=Y$ (accessed on 14 July 2021).

85. Fisheries Agency, Taiwan. National Plan of Action of the Republic of China (Taiwan) to Prevent, Deter, and Eliminate Illegal, Unreported and Unregulated (IUU) Fishing. Available online: https:/ /www.fa.gov.tw/upload/456/2016040714524636661.pdf (accessed on 14 July 2021).

86. National Oceanic and Atmospheric Administration, the United States. NOAA Issues 2021 Report on Global IUU Fishing and Bycatch of Protected Marine Life Resources. Available online: https://www.fisheries.noaa.gov/feature-story/noaa-issues-2021 -report-global-iuu-fishing-and-bycatch-protected-marine-life-resources (accessed on 30 August 2021).

87. Fisheries Agency, Japan. Suisan Yosan, Kessan no Gaiyo [Summary of the Budget and the Settlement Account of Fisheries] (in Japanese). Available online: https://www.jfa.maff.go.jp/j/budget/ (accessed on 30 August 2021).

88. Puspitawati, D.; Hadiyantina, S.; Susanto, F.A.; Apriyanti, N. Law Enforcement at Indonesian Waters: Bakamla vs. Sea and Coast Guard. Indones. J. Int. Law 2020, 17, 495-518. [CrossRef]

89. SeafoodSource. Indonesia Creates Intelligence Hub to Curb Illegal Fishing. Available online: https://www.seafoodsource.com/ news/environment-sustainability/indonesia-creates-intelligence-hub-to-curb-illegal-fishing (accessed on 29 August 2021).

90. Busro, Z.M. Burning and/or Sinking Foreign Fishing Vessels Conducting Illegal Fishing in Indonesia: Some Obligations and Loopholes. Asia-Pac. J. Ocean. Law Policy 2017, 2, 174-179. [CrossRef]

91. Mongobay. Everything's Moving: Indonesia Seeks Global Pushback on Illegal Fishing. Available online: https://news.mongabay. com/2019/01/everythings-moving-indonesia-seeks-global-pushback-on-illegal-fishing/ (accessed on 29 August 2021).

92. Southeast Asian Fisheries Development Center. Regional Cooperation to Support Implement of Port State Measures (PSM) in ASEAN. Available online: http:/ / www.seafdec.or.th/home/fishery-knowledge/iuu/port-state-measures (accessed on 14 July 2021).

93. Royal Thai Embassy, Brussels. CCCIF Press Release: Thailand's Progress in Combating IUU Fishing. Available online: https: //www.thaiembassy.be/2016/01/20/press-release-thailands-progress-in-combating-iuu-fishing/?lang=en (accessed on 14 July 2021).

94. Department of Fisheries, Thailand. Thailand's Success in Combating IUU Fishing. Available online: https://www4.fisheries.go. th/dof_en/view_message/232 (accessed on 14 July 2021).

95. OceanMind. Stop IUU Fishing Award Runner-Up. Available online: https://www.oceanmind.global/insights/stop-iuu-fishingaward-runner-up/ (accessed on 14 July 2021).

96. The World Bank. Bangladesh Sustainable Coastal and Marine Fisheries. Available online: https://projects.worldbank.org/en/ projects-operations / project-detail/P161568 (accessed on 14 July 2021).

97. Rahman, M.A.; Lee, S.G.; Molla, M.H.R.; Asare, O.E. Fisheries management and governance in Bangladesh. MOJ Eco. Environ. Sci. 2018, 3, 381-385. [CrossRef]

98. Indian Ocean Tuna Commission. Electronic Data Verification Module with Vessel Tracking Facility to Combat IUU Fishing. Available online: https:/ / www.iotc.org/documents/electronic-data-verification-module-vessel-tracking-facility-combat-iuufishing (accessed on 14 July 2021).

99. Department of Fisheries and Aquatic Resources, Sri Lanka. Sri Lanka National Plan of Action to Prevent, Deter and Eliminate Illegal, Unreported and Unregulated Fishing. Available online: http://www.fao.org/3/bl359e/bl359e.pdf (accessed on 14 July 2021).

100. Food and Agricultural Organization of the United Nations. Report on Cost-Benefit Analysis of the Monitoring, Control and Surveillance (MCS) System and Tools Developed by Sri Lanka. Available online: http://www.fao.org/3/ca2832en/CA2832EN pdf (accessed on 14 July 2021). 
101. Indian Ocean Tuna Commission. Sri Lanka National Report to the Scientific Committee of the Indian Ocean Tuna Commission. 2020. Available online: https://www.iotc.org/documents/SC/23/NR21 (accessed on 14 July 2021).

102. Pacific Islands Forum Fisheries Agency. Operation Island Chief Conducts Surveillance Across PNG, FSM, RMI, Nauru and Kiribati Waters. Available online: https:/ / www.ffa.int/operation_island_chief_2010 (accessed on 14 July 2021).

103. Pacific Islands Forum Fisheries Agency. Niue Treaty on Cooperation in Fisheries Surveillance and Law Enforcement in the South Pacific Region. Available online: https:/ / www.ffa.int/system/files/Niue\%20Treaty_0.pdf (accessed on 14 July 2021).

104. Pacific Islands Forum Fisheries Agency. Agreement on Strengthening Implementation of the Niue Treaty on Cooperation in Fisheries Surveillance and Law Enforcement in the South Pacific Region. Available online: https://www.ffa.int/system/files / Niue_Treaty_Subsidiary_Agreement_NTSA_-_Final_text.pdf (accessed on 14 July 2021).

105. Pacific Islands Forum Fisheries Agency. Key Surveillance Operation Concludes this Week in FSM \& Palau. Available online: https:/ / www.ffa.int/node/238 (accessed on 14 July 2021).

106. Department of Defence, Australian Governmet. Pacific Maritime Security Program. Available online: https://www.defence.gov. au/annualreports/17-18/features/maritime.asp (accessed on 14 July 2021).

107. Japan Association of Marine Safety. 2017 Nendo Micronesia Sangoku no Kaijo Hoan Noryoku Kyoka Shien Jigyo Hokoku-sho [Report on the Technical Cooperation for Enhancement of the Maritime Security Capability in Three Micronesian Countries in 2017] (in Japanese). Available online: https://nikkaibo.or.jp/pdf/30_02.pdf (accessed on 14 July 2021).

108. Pramod, G. Global Evaluation of Fisheries Monitoring Control and Surveillance in 84 Countries, Federated States of MicronesiaCountry Report. Available online: https:/ /iuuriskintelligence.com/wp-content/uploads/2018/03/Micronesia-country-ReportGlobal-Fisheries-MCS-Report-2018.pdf (accessed on 14 July 2021).

109. Southeast Asian Fisheries Development Center. Regional Fishing Vessels Record (RFVR): A Tool to Combat the IUU Fishing in Southeast Asian Region. Available online: http:/ / www.seafdec.org/documents/2015/11/18fcgwp0621.pdf (accessed on 29 August 2021).

110. Southeast Asian Fisheries Development Center. ASEAN Catch Documentation Scheme for Marine Capture Fisheries. Available online: https:/ / asean.org/wp-content/uploads/2012/05/16.-ASEAN-Catch-Documentation-Scheme.pdf (accessed on 29 August 2021).

111. The Bay of Bengal Programme Inter-Governmental Organisation. Regional Consultation on the Development of the Regional Plan of Action to Combat Illegal, Unreported and Unregulated Fishing. Available online: https://www.bobpigo.org/webroot/ $\mathrm{img} / \mathrm{pdf} /$ Report-IUU-October2019-FINAL.pdf (accessed on 29 August 2021).

112. Cabral, R.B.; Mayorga, J.; Clemence, M.; Lynham, J.; Koeshendrajana, S.; Muawanah, U.; Nugroho, D.; Anna, Z.; Mira; Ghofar, A.; et al. Rapid and lasting gains from solving illegal fishing. Nat. Ecol. Evol. 2018, 2, 650-658. [CrossRef] [PubMed]

113. Pacific Islands Forum Fisheries Agency. Surveillance Operation Rai Balang Shows Success in Deterring Illegal Fishing. Available online: https:/ / www.ffa.int/node/333 (accessed on 14 July 2021).

114. Fisheries Agency, Japan. Suisancho no Torishimari [Fisheries Surveillance by the Fisheires Agency] (in Japanese). Available online: https://www.jfa.maff.go.jp/j/koho/pr/pamph/attach/pdf/index-10.pdf (accessed on 29 August 2021).

115. Fisheries Agency, Japan. Reiwa Ninen no Gaikokugyosen Torishimari Jisseki ni Tsuite [Regarding the Results of the Surveillance of Foreign Fishing Vessels in 2020] (in Japanese). Available online: https://www.jfa.maff.go.jp/j/press/kanri/210312.html (accessed on 14 July 2021).

116. Taipei Times. Fishers Protest Strict Rules while Groups Laud them. Available online: https://www.taipeitimes.com/News/ front/archives/2018/11/07/2003703741 (accessed on 14 July 2021).

117. Food and Agricultural Organization of the United Nations. A Review of Illegal, Unreported and Unregulated Fishing Issues and Progress in the Asia-Pacific Fishery Commission Region. Available online: http://www.fao.org/3/cb2640en/cb2640en.pdf (accessed on 14 July 2021).

118. United States International Trade Commission. Seafood Obtained via Illegal, Unreported, and Unregulated Fishing: U.S. Imports and Economic Impact on U.S. Commercial Fisheries. Available online: https:/ / www.usitc.gov/publications/332/pub5168.pdf (accessed on 14 July 2021).

119. Indian Ocean Tuna Commission. Resolution 10/04 on a Regional Observer Scheme. Available online: https: / /www.iotc.org/ $\mathrm{cmm}$ / resolution-1004-regional-observer-scheme (accessed on 14 July 2021).

120. Ministry of Agriculture, Forestry and Fisheries, Japan. Gyoson no Genjo ni Kansuru Toke [Statistics about the Current Status of Fisheries Villages] (in Japanese). Available online: https:/ / www.maff.go.jp/j/tokei/sihyo/data/19.html (accessed on 14 July 2021).

121. Fisheries Agency, Japan. Daijin Kyoka Gyogyo no Kyoka ni Kansuru Joho no Kokai ni Tsuite [Regarding publication of the information about the permission of the fisheries permitted by the Minister of Agriculture, Forestry and Fisheries] (in Japanese). Available online: https:/ / www.jfa.maff.go.jp/j/kikaku/sitei/ (accessed on 14 July 2021).

122. Department of Fisheries, Thailand.Thailand Fisheries Statistic. Available online: https://www4.fisheries.go.th/dof_en/view_ message/233 (accessed on 14 July 2021).

123. Pew Charitable Trust. With High-Tech Eyes, Authorities Corner Illegal Fishers. Available online: https://www.pewtrusts.org/ en/research-and-analysis/articles/2017/11/13/with-high-tech-eyes-authorities-corner-illegal-fishers (accessed on 14 July 2021).

124. Parties to the Nauru Agreement. PNA: Fisheries Observers are our "Eyes at Sea". Available online: https://www.pnatuna.com/ content/pna-fisheries-observers-are-our-\%E2\%80\%9Ceyes-sea $\%$ E2\%80\%9D (accessed on 14 July 2021). 
125. Embassy of the Federated States of Micronesia, Washington, DC. Monitoring for Sustainable Fisheries. Available online: https://fsmembassy.fm/fsm-pushes-forward-to-be-first-pacific-island-to-fully-establish-electronic-monitoring-forsustainable-fisheries / (accessed on 14 July 2021).

126. Parties to the Nauru Agreement. PNA Maintains World-Class CoC during COVID-19 Crisis. Available online: https://www. pnatuna.com/content/pna-maintains-world-class-coc-during-covid-19-crisis (accessed on 14 July 2021).

127. Food and Agriculture Organization of the United Nations. Fishing for Development. Available online: http://www.fao.org/3/i4 468e/i4468e.pdf (accessed on 14 July 2021).

128. Handl, G. Flag State Responsibility for Illegal, Unreported and Unregulated Fishing in Foreign EEZs. Environ. Policy Law 2014, 44, 158-171.

129. Schmidt, C.C. Economic drivers of illegal, unreported and unregulated (IUU) fishing. Int. J. Mar. Coast. Law 2005, 20, 479-507. [CrossRef]

130. Petrossian, G.A. Preventing illegal, unreported and unregulated (IUU) fishing: A situational approach. Biol. Conserv. 2015, 189, 39-48. [CrossRef]

131. Ballesteros, H.M.; Rodríguez-Rodríguez, G. "Acceptable" and "unacceptable" poachers: Lessons in managing poaching from the Galician shellfish sector. Mar. Policy 2018, 87, 104-110. [CrossRef]

132. De la Puente, S.; López De La Lama, R.; Benavente, S.; Sueiro, J.C.; Pauly, D. Growing into poverty: Reconstructing Peruvian small-scale fishing effort between 1950 and 2018. Front. Mar. Sci. 2020, 7, 681. [CrossRef]

133. Raemaekers, S.; Hauck, M.; Bürgener, M.; Mackenzie, A.; Maharaj, G.; Plagányi, É.E.; Britz, P.J. Review of the causes of the rise of the illegal South African abalone fishery and consequent closure of the rights-based fishery. Ocean Coast. Manag. 2011, 54, 433-445. [CrossRef]

134. Iacarella, J.C.; Clyde, G.; Bergseth, B.J.; Ban, N.C. A synthesis of the prevalence and drivers of non-compliance in marine protected areas. Biol. Conserv. 2021, 255, 108992:1-108992:12. [CrossRef]

135. Lee, J. Subsidies for Illegal Activities?-Reframing IUU Fishing from the Law Enforcement Perspective. J. Int. Econ. Law 2019, 22, 417-438. [CrossRef]

136. Food and Agriculture Organization of the United Nations. Voluntary Guidelines for Securing Sustainable Small-Scale Fisheries in the Context of Food Security and Poverty Eradication. Available online: http:/ / www.fao.org/3/i4356en/I4356EN.pdf (accessed on 14 July 2021).

137. Ballesteros, H.M.; Rodríguez-Rodríguez, G. Economic crisis and poaching: Advice on anti-poaching management from the Galician Shellfish Sector. Deviant Behav. 2019, 40, 1508-1521. [CrossRef]

138. Stead, S.M. Rethinking marine resource governance for the united Nations sustainable development goals. Curr. Opin. Environ. Sustain. 2018, 34, 54-61. [CrossRef]

139. Zhou, S.; Smith, A.D.; Knudsen, E.E. Ending overfishing while catching more fish. Fish Fish. 2015, 16, 716-722. [CrossRef]

140. Lee, J.; South, A.B.; Jennings, S. Developing reliable, repeatable, and accessible methods to provide high-resolution estimates of fishing-effort distributions from vessel monitoring system (VMS) data. ICES J. Mar. Sci. 2010, 67, 1260-1271. [CrossRef]

141. Chang, S.K. Application of a vessel monitoring system to advance sustainable fisheries management-Benefits received in Taiwan. Mar. Policy 2011, 35, 116-121. [CrossRef]

142. Thiault, L.; Weekers, D.; Curnock, M.; Marshall, N.; Pert, P.L.; Beeden, R.; Dyer, M.; Claudet, J. Predicting poaching risk in marine protected areas for improved patrol efficiency. J. Environ. Manag. 2020, 254, 109808. [CrossRef]

143. Peacock, S.J.; Mavrot, F.; Tomaselli, M.; Hanke, A.; Fenton, H.; Nathoo, R.; Aleuy, O.A.; Di Francesco, J.; Aguilar, X.F.; Jutha, N.; et al. Linking co-monitoring to co-management: Bringing together local, traditional, and scientific knowledge in a wildlife status assessment framework. Arct. Sci. 2020, 6, 247-266. [CrossRef]

144. Obiero, K.O.; Abila, R.O.; Njiru, M.J.; Raburu, P.O.; Achieng, A.O.; Kundu, R.; Ogello, E.O.; Munguti, J.M.; Lawrence, T. The challenges of management: Recent experiences in implementing fisheries co-management in Lake Victoria, Kenya. Lakes Reserv. Res. Manag. 2015, 20,139-154. [CrossRef]

145. Swan, J. IUU Fishing and Measures to Improve Enforcement and Compliance. In The Future of Ocean Governance and Capacity Development; Brill Nijhoff: Leiden, The Netherlands, 2019; pp. 354-360. ISBN 978-90-04-38027-1.

146. Uhlmann, S.S.; Ulrich, C.; Kennelly, S.J. (Eds.) The European Landing Obligation: Reducing Discards in Complex, Multi-Species and Multi-Jurisdictional Fisheries; Springer Nature: Basingstoke, UK, 2019; p. 431.

147. Ewell, C.; Hocevar, J.; Mitchell, E.; Snowden, S.; Jacquet, J. An evaluation of Regional Fisheries Management Organization at-sea compliance monitoring and observer programs. Mar. Policy 2020, 115, 103842:1-103842:12. [CrossRef]

148. Sylvia, G.; Harte, M.; Cusack, C. Challenges, Opportunities, and Costs of Electronic Fisheries Monitoring. Available online: https://www.edf.org/sites/default/files/electronic_monitoring_for_fisheries_report_-_september_2016.pdf (accessed on 14 July 2021).

149. Van Helmond, A.T.; Mortensen, L.O.; Plet-Hansen, K.S.; Ulrich, C.; Needle, C.L.; Oesterwind, D.; Kindt-Larsen, L.; Catchpole, T.; Mangi, S.; Zimmermann, C.; et al. Electronic monitoring in fisheries: Lessons from global experiences and future opportunities. Fish Fish. 2020, 21, 162-189. [CrossRef]

150. Doulman, D.J.; Swan, J. A Guide to the Background and Implementation of the 2009 FAO Agreement on Port State Measures to Prevent, Deter and Eliminate Illegal, Unreported and Unregulated Fishing. FAO Fisheries and Aquaculture Circular, (C1074), I. Available online: http:/ / www.fao.org/3/i2590e/i2590e00.pdf (accessed on 14 July 2021). 
151. Valančiūnas, D. Haunting memories: Sri Lankan civil war, trauma and diaspora in literature and film. South Asian Diaspora 2021, 13, 37-49. [CrossRef]

152. Pham, J.P. Putting Somali piracy in context. J. Contemp. Afr. Stud. 2010, 28, 325-341. [CrossRef]

153. Doumbouya, A.; Camara, O.T.; Mamie, J.; Intchama, J.F.; Jarra, A.; Ceesay, S.; Guèye, A.; Ndiaye, D.; Beibou, E.; Padilla, A.; et al. Assessing the effectiveness of monitoring control and surveillance of illegal fishing: The case of West Africa. Front. Mar. Sci. 2017, 4, 50:1-50:10. [CrossRef] 